\title{
Complement C1q Subcomponent Subunit
} A

National Cancer Institute

\section{Source}

National Cancer Institute. Complement C1q Subcomponent Subunit A. NCI Thesaurus. Code C105381.

Complement C1q subcomponent subunit A (245 aa, $26 \mathrm{kDa}$ ) is encoded by the human C1QA gene. This protein plays a role in the activation of the classical complement pathway. 